Article

\title{
Levantilides A and B, 20-Membered Macrolides from a Micromonospora Strain Isolated from the Mediterranean Deep Sea Sediment
}

\author{
Andrea Gärtner, Birgit Ohlendorf, Dirk Schulz, Heidi Zinecker ${ }^{\dagger}$, Jutta Wiese and \\ Johannes F. Imhoff *
}

Kieler Wirkstoff-Zentrum (KiWiZ) at the IFM-GEOMAR (Leibniz Institute of Marine Sciences), Am Kiel-Kanal 44, 24106 Kiel, Germany; E-Mails: agaertner@ifm-geomar.de (A.G.);

bohlendorf@ifm-geomar.de (B.O.); dschulz@ifm-geomar.de (D.S.);

heidi.zinecker@uni-bonn.de (H.Z.); jwiese@ifm-geomar.de (J.W.)

$\dagger$ Present address: Universität Bonn, Pharmazeutisches Institut, Pharmazeutische Chemie I, An der Immenburg 4, 53121 Bonn, Germany.

* Author to whom correspondence should be addressed; E-Mail: jimhoff@ifm-geomar.de;

Tel.: +49-431-600-4450; Fax: +49-431-600-4452.

Received: 22 November 2010; in revised form: 22 December 2010 / Accepted: 13 January 2011 / Published: 14 January 2011

\begin{abstract}
Two new 20-membered macrolides, levantilide A and B, were isolated from the Micromonospora strain M71-A77. Strain M71-A77 was recovered from an Eastern Mediterranean deep-sea sediment sample and revealed to produce the levantilides under in situ salinity of $38.6 \%$. The chemical structures of the levantilides were elucidated on the basis of different one- and two- dimensional NMR experiments. Levantilide A exhibits a moderate antiproliferative activity against several tumor cell lines.
\end{abstract}

Keywords: macrolide; Micromonospora; deep sea; natural product; marine

\section{Introduction}

The deep sea is an extreme environment which is still marginally investigated and harbors a great variety of bacteria that have, so far, not been cultivated. Bacteria which live in the deep sea need to adapt to the specific environmental characteristics such as high hydrostatic pressure, low temperature and only occasional nutrient supply. These constraints quite likely determine the phylogenetic 
diversity of the deep-sea bacterial communities and also affect the secondary metabolite production of these bacteria. Therefore, deep-sea bacteria are considered as a promising source for the discovery of new natural products. Marine members of Actinobacteria are highly potent producers of interesting compounds [1-5] as was already shown for their terrestrial counterparts [6]. Only recently, two strains of Streptomyces sp. from the Atlantic ocean deep-sea sediment were shown to produce the two new natural products caboxamycin and albidopyrone $[7,8]$.

With special focus on the discovery of new natural products, we selectively isolated Actinobacteria from the deep-sea sediment of the Eastern Mediterranean Sea (the so-called Levantine Sea). This environment is characterized by a relatively high bottom temperature of $13-14^{\circ} \mathrm{C}$, salinity values of approximately 38-39\%, high hydrostatic pressure (440 bar at the sampling site) and an extreme depletion of nutrients [9]. Among the isolated bacteria, strain M71-A77 produced two new macrolides named levantilides A (1) and B (2), which will be described in this paper.

\section{Results and Discussion}

Strain M71-A77 was isolated from the Eastern Mediterranean deep-sea sediment (4400 m) and revealed $99.3 \%$ 16S rRNA gene sequence similarity to Micromonospora auratinigra DSM $44815^{\mathrm{T}}$ (AB159779). Analyses of the culture extract of this strain (incubated in liquid soja-peptone medium) by HPLC-DAD-MS led to the detection of two unknown 20-membered macrolides, levantilide A (1) and B (2), with detected masses of $m / z, 508$ and $m / z, 506$, respectively. Subsequent cultivation of the strain in larger scale $(10 \mathrm{~L})$ led to the isolation of the levantilides as colorless solids.

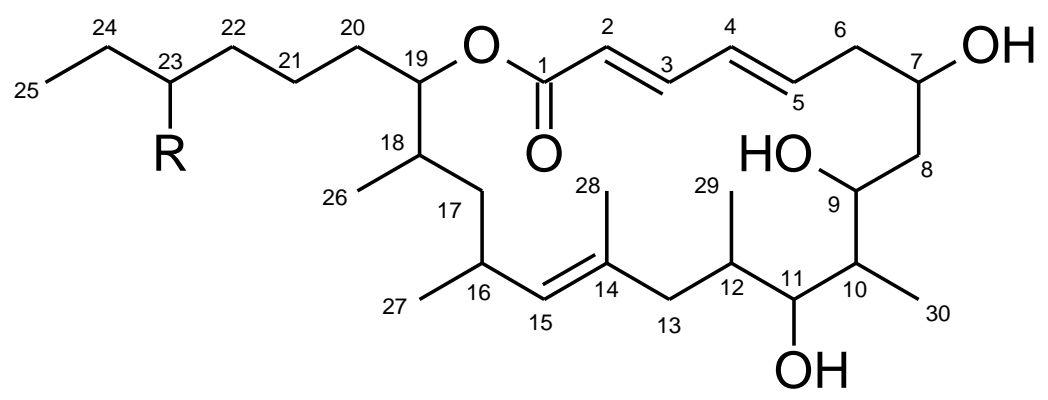

Levantilide A (1) $\mathrm{R}=-\mathrm{OH}$

Levantilide $\mathrm{B}(\mathbf{2}) \mathrm{R}=\mathrm{O}$

Levantilide A (1) had a measured molecular mass of $\mathrm{m} / z 531.3676[\mathrm{M}+\mathrm{Na}]^{+}$(calculated for $\mathrm{C}_{30} \mathrm{H}_{52} \mathrm{NaO}_{6}$ 531.3656), which yielded the molecular formula $\mathrm{C}_{30} \mathrm{H}_{52} \mathrm{O}_{6}$ and implied five degrees of unsaturation. The structure elucidation of the compound was mainly based on one- and twodimensional NMR spectra of 1 . The respective ${ }^{13} \mathrm{C}$ NMR spectrum displayed 30 distinct signals (Table 1) which were consistent with the deduced molecular formula. The carbon resonances gave evidence of one carbonyl carbon $\left(\delta_{\mathrm{C}} 166.1 \mathrm{ppm}\right)$, one olefinic quaternary carbon $\left(\delta_{\mathrm{C}} 132.8 \mathrm{ppm}\right)$, five olefinic methine carbons $\left(\delta_{\mathrm{C}} 120.4 \mathrm{ppm}\right.$ to $143.8 \mathrm{ppm}$ ), five methine carbons adjacent to oxygen atoms $\left(\delta_{\mathrm{C}} 67.2 \mathrm{ppm}\right.$ to $77.4 \mathrm{ppm}$ ), four further methine carbons ( $\delta_{\mathrm{C}} 29.4 \mathrm{ppm}$ to $41.0 \mathrm{ppm}$ ), eight methylene groups $\left(\delta_{\mathrm{C}} 22.0 \mathrm{ppm}\right.$ to $\left.40.9 \mathrm{ppm}\right)$ and six methyl groups ( $\delta_{\mathrm{C}} 10.1 \mathrm{ppm}$ to $\left.21.5 \mathrm{ppm}\right)$. The HSQC spectrum allowed all carbon resonances to be unambiguously assigned to the resonances of their 
directly attached protons. The final planar structure of the molecule was deduced from COSY and HMBC spectra (Figure 1). With a shift of $166.1 \mathrm{ppm}$, the carbonyl carbon C-1 was very likely to belong to a conjugated ester function. HMBC correlations from $\mathrm{H}-3\left(\delta_{\mathrm{H}} 7.06\right)$ and $\mathrm{H}-2\left(\delta_{\mathrm{H}} 5.78\right)$ identified the adjacent methine groups. $\mathrm{H}-2$ to $\mathrm{H}-5\left(\delta_{\mathrm{H}} 6.08\right)$ were all olefinic protons which coupled to each other. H-5 showed HMBC correlations to C-3 $\left(\delta_{C} 143.8\right)$ as well as to C-6 $\left(\delta_{C} 39.6\right)$, a methylene carbon, and C-7 $\left(\delta_{\mathrm{C}} 67.2\right)$, a hydroxylated methine. H-7 $\left(\delta_{\mathrm{H}} 3.98\right)$ showed COSY correlations to H-6 as well as to the methylene group $\mathrm{CH}_{2}-8\left(\delta_{\mathrm{C}} 33.4, \delta_{\mathrm{H}} 1.51 ; 1.16\right)$. Next to $\mathrm{CH}_{2}-8$, there followed four methine groups, $\mathrm{CH}-9$ to $\mathrm{CH}-12$, each of them substituted with either a hydroxy group, $\mathrm{CH}-9\left(\delta_{\mathrm{C}} 67.4\right.$, $\left.\delta_{\mathrm{H}} 3.92\right)$ and $\mathrm{CH}-11\left(\delta_{\mathrm{C}} 75.3 ; \delta_{\mathrm{H}} 2.98\right)$, or a methyl group, $\mathrm{CH}-10\left(\delta_{\mathrm{C}} 41.0 ; \delta_{\mathrm{H}} 1.68\right)$ and $\mathrm{CH}-12$ $\left(\delta_{\mathrm{C}} 32.1\right.$ and $\left.\delta_{\mathrm{H}} 1.24\right)$, which could be unequivocally proven by their shifts, COSY and HMBC correlations. Not only did the COSY correlations of the methyl groups $\mathrm{CH}_{3}-29\left(\delta_{\mathrm{C}} 17.7\right.$ and $\left.\delta_{\mathrm{H}} 0.58\right)$ and $\mathrm{CH}_{3}-30\left(\delta_{\mathrm{C}} 11.1\right.$ and $\left.\delta_{\mathrm{H}} 0.86\right)$ connect them to the methine groups $\mathrm{CH}-12$ and $\mathrm{CH}-10$, but their HMBC correlations also gave further evidence of the positions of the neighboring carbons and secured the sequence from $\mathrm{CH}-9$ to $\mathrm{CH}-12$. Furthermore, a methylene group $\mathrm{CH}_{2}-13\left(\delta_{\mathrm{C}} 40.1, \delta_{\mathrm{H}} 1.87\right.$ and 1.51) was shown to connect the methine groups $\mathrm{CH}-9$ to $\mathrm{CH}-12$ to the quaternary olefinic carbon $\mathrm{C}-14$ $\left(\delta_{\mathrm{C}} 132.8\right)$. Therefore, the last double bond evidently was located between $\mathrm{C}-14$ and $\mathrm{C}-15\left(\delta_{\mathrm{C}} 132.7\right)$. The corresponding proton $\mathrm{H}-15\left(\delta_{\mathrm{H}} 4.76\right)$ showed long range couplings to $\mathrm{C}-17\left(\delta_{\mathrm{C}} 40.9\right), \mathrm{C}-13, \mathrm{C}-16$ $\left(\delta_{\mathrm{C}} 29.4\right), \mathrm{C}-27\left(\delta_{\mathrm{C}} 21.5\right)$ and $\mathrm{C}-28\left(\delta_{\mathrm{C}} 17.0\right)$ and coupled to $\mathrm{H}-16$ and $\mathrm{H}_{2}-13 . \mathrm{CH}_{2}-17\left(\delta_{\mathrm{H}} 1.34\right.$ and 1.05) formed the junction between the methyl-bearing methines $\mathrm{CH}-16$ and $\mathrm{CH}-18$ as indicated by HMBC correlations from $\mathrm{H}-17$ to $\mathrm{C}-18\left(\delta_{\mathrm{C}} 33.4\right), \mathrm{C}-26\left(\delta_{\mathrm{C}} 17.5\right)$ and C-27. The substructure was further supported by COSY correlations of the same proton signal (H-17) to the resonances of $\mathrm{H}-16$ $\left(\delta_{\mathrm{H}} 2.59\right)$ and $\mathrm{H}-18\left(\delta_{\mathrm{H}} 1.75\right) . \mathrm{CH}-19\left(\delta_{\mathrm{C}} 77.4 ; \delta_{\mathrm{H}} 4.71\right)$, the methine adjacent to $\mathrm{CH}-18$, closed the macrolide ring as proven by its $\mathrm{HMBC}$ correlation to $\mathrm{C}-1$ and connected it to the side chain of the molecule by correlations to the methylene groups $\mathrm{CH}_{2}-20\left(\delta_{\mathrm{C}} 27.9 ; \delta_{\mathrm{H}} 1.52\right.$ and 1.47$)$ and $\mathrm{CH}_{2}-21$ $\left(\delta_{\mathrm{C}} 22.0 ; \delta_{\mathrm{H}} 1.30\right)$. After the carbonyl group and the three double bonds, one degree of unsaturation still had to be accounted for, which was accomplished by the closure of the ring. Analysis of the NMR spectra gave evidence of a 3-hydroxy-hexyl-side chain. All double bonds, $\Delta^{2,3}, \Delta^{4,5}$ and $\Delta^{14,15}$, were determined to be $E$-configured. For the double bonds $\Delta^{2,3}$ and $\Delta^{4,5}$, the configuration was deduced from the ${ }^{3} J$ coupling constants of approximately $15 \mathrm{~Hz} \cdot \Delta^{14,15}$ is a trisubstituted double bond, therefore the NOESY spectrum had to be consulted. As H-15 showed NOESY-correlations to $\mathrm{H}_{2}-13$, but not to $\mathrm{H}_{3}-28$, this double bond, too, had to be $E$-configured. Thus, the planar structure of levantilide A could be unambiguously delineated from the spectroscopic data.

The derivative, levantilide B (2), showed a mass difference of 2 amu in the HPLC-DAD-MS measurement, which indicated one additional double bond, which for example can be observed, when a hydroxy-group is replaced by a carbonyl function, as it was the case here. Already in the ${ }^{1} \mathrm{H}$ NMR spectrum it was obvious that all signals belonging to protons of the macrolide ring were identical in both molecules (see Table 2). However, significant differences could be observed for the signals of the side chain. Analysis of the data showed that the methine group $\mathrm{CH}-23$ was no longer present in levantilide B. Instead of it, an additional signal of a carbonyl carbon appeared, its shift of $210.5 \mathrm{ppm}$ proving it to be a ketone. As a consequence of the presence of a carbonyl group instead of a methine in position 23, the signal of $\mathrm{H}_{2}-24$ was no longer a multiplet, but appeared as a quartet as it only coupled with the methyl group $\mathrm{CH}_{3}-25$. Thus, the planar structure of 2 was established as depicted. 
Table 1. NMR spectroscopic data (500 MHz, DMSO- $d_{6}$ ) of levantilide A (1).

\begin{tabular}{|c|c|c|c|c|c|}
\hline \multicolumn{6}{|c|}{ levantilide A (1) } \\
\hline position & $\delta_{\mathrm{C}}$ & $\delta_{\mathrm{H}}, J[\mathrm{~Hz}]$ & COSY & НMBC & NOESY \\
\hline 1 & $166.1, \mathrm{C}$ & & & & \\
\hline 2 & $120.4, \mathrm{CH}$ & $5.78, d(15.5)$ & 3 & $1,3,4,5$ & 3,4 \\
\hline 3 & $143.8, \mathrm{CH}$ & $7.06, \mathrm{dd}(11.2,15.5)$ & 2,4 & $1,2,4,5$ & $2,4,5$ \\
\hline 4 & $130.6, \mathrm{CH}$ & $6.29, \mathrm{dd}(11.2,15.2)$ & 3,5 & $2,3,6$ & $2,3,5,6 b$ \\
\hline 5 & $139.8, \mathrm{CH}$ & $6.08, \operatorname{ddd}(4.4,10,15.2)$ & 4,6 & $3,6,7$ & $3,4,6 a, 7$ \\
\hline $6 a$ & $39.6, \mathrm{CH}_{2}$ & 2.57, m & $5,6 b, 7$ & $4,5,7,8$ & 5 \\
\hline $6 b$ & & 2.33, dt $(14.4,9.9)$ & $5,6 a, 7$ & $4,5,7,8$ & 4 \\
\hline 7 & $67.2, \mathrm{CH}$ & $3.98, \mathrm{~m}$ & $6,7-\mathrm{OH}, 8$ & & $8 b, 5$ \\
\hline 7-OH & & 4.81, br. d (3.8) & 7 & 7,8 & \\
\hline $8 a$ & $33.4, \mathrm{CH}_{2}$ & $1.51^{\mathrm{a}}, \mathrm{m}$ & $7,8 b, 9$ & $6,7,9$ & $8 b$ \\
\hline $8 b$ & & 1.16 , ddd $(14.6,5.6,2.3)$ & $7,8 \mathrm{a}, 9$ & $6,7,9$ & $7,8 \mathrm{a}, 11$ \\
\hline 9 & $67.4, \mathrm{CH}$ & 3.92, br. d (11.2) & $8,9-\mathrm{OH}, 10$ & 30 & 12 \\
\hline 9-OH & & 4.63, br. s & 9 & $8,9,10$ & \\
\hline 10 & $41.0, \mathrm{CH}$ & $1.68, \mathrm{~m}$ & $9,11,30$ & & \\
\hline 11 & $75.3, \mathrm{CH}$ & 2.98 br. ddd $(8.9,6.0,1.8)$ & $10,11-\mathrm{OH}, 12$ & $9,10,12,13,29,30$ & $8 b, 29$ \\
\hline $11-\mathrm{OH}$ & & $4.00, \mathrm{~d}(6.0)$ & 11 & $10,11,12$ & \\
\hline 12 & $32.1, \mathrm{CH}$ & $1.24, \mathrm{~m}$ & $11,13,29$ & & 9 \\
\hline $13 \mathrm{a}$ & $40.1, \mathrm{CH}_{2}$ & 1.87, br. d (12.8) & $12,13 b, 15,29$ & $11,12,14,15,27,28,29$ & $13 b$ \\
\hline $13 b$ & & $1.51^{\mathrm{a}}, \mathrm{m}$ & $12,13 a, 15,29$ & $11,12,14,15,27,28,29$ & $13 \mathrm{a}, 15$ \\
\hline 14 & $132.8, \mathrm{C}$ & & & & \\
\hline 15 & 132.7, $\mathrm{CH}$ & $4.76, \mathrm{~d}(7.8)$ & 13,16 & $12,13,16,17,27,28$ & $13 \mathrm{~b}, 17,29$ \\
\hline 16 & $29.4, \mathrm{CH}$ & $2.59, \mathrm{~m}$ & $15,17,27$ & $14,17,27$ & 27,28 \\
\hline $17 \mathrm{a}$ & $40.9, \mathrm{CH}_{2}$ & $1.34, \mathrm{~m}$ & $16,17 b, 18$ & $15,16,18,19,26,27$ & $17 b$ \\
\hline $17 b$ & & 1.05, ddd $(13.5,8.7,5.0)$ & $16,17 \mathrm{a}, 18$ & $15,16,18,19,26,27$ & $17 \mathrm{a}, 27$ \\
\hline 18 & $33.4, \mathrm{CH}$ & $1.75, \mathrm{~m}$ & $17,19,26$ & $16,17,19,20,26$ & \\
\hline 19 & $77.4, \mathrm{CH}$ & 4.71, dt $(10,2.4)$ & 18,20 & $1,17,20,21,26$ & 21,26 \\
\hline $20 \mathrm{a}$ & $27.9, \mathrm{CH}_{2}$ & $1.52^{\mathrm{a}}, \mathrm{m}$ & 19,21 & & \\
\hline $20 \mathrm{~b}$ & & $1.47^{\mathrm{a}}, \mathrm{m}$ & 19,21 & & \\
\hline 21 & $22.0, \mathrm{CH}_{2}$ & $1.30^{\mathrm{b}}, \mathrm{m}$ & 20 & & 19 \\
\hline 22 & $36.1, \mathrm{CH}_{2}$ & $1.31^{\mathrm{b}}, \mathrm{m}$ & 23 & & $23,23-\mathrm{OH}$ \\
\hline 23 & $70.8, \mathrm{CH}$ & $3.28, \mathrm{~m}$ & $22,23-\mathrm{OH}, 24$ & $21,22,25$ & $22,25,26$ \\
\hline $23-\mathrm{OH}$ & & $4.25, \mathrm{~d}(5.2)$ & 23 & $22,23,24$ & 22,26 \\
\hline $24 \mathrm{a}$ & 29.7, $\mathrm{CH}_{2}$ & $1.30^{\mathrm{b}}, \mathrm{m}$ & 23,25 & & 25 \\
\hline $24 \mathrm{~b}$ & & $1.27^{\mathrm{b}}, \mathrm{m}$ & 23,25 & & 25 \\
\hline 25 & $10.1, \mathrm{CH}_{3}$ & $0.82, \mathrm{t}(7.4)$ & 24 & 23,24 & 23,24 \\
\hline 26 & $17.5, \mathrm{CH}_{3}$ & $0.88, \mathrm{~d}(6.2)$ & 18 & $17,18,19$ & $\begin{array}{c}19,23,23- \\
\mathrm{OH}\end{array}$ \\
\hline 27 & 21.5, $\mathrm{CH}_{3}$ & $0.84, \mathrm{~d}(6.8)$ & 16 & $15,16,17$ & $16,17 \mathrm{~b}$ \\
\hline 28 & $17.0, \mathrm{CH}_{3}$ & $1.53^{\mathrm{a}}, \mathrm{s}$ & & $13,14,15$ & 16 \\
\hline 29 & $17.7, \mathrm{CH}_{3}$ & $0.58, \mathrm{~d}(6.7)$ & 12 & $11,12,13$ & 11,15 \\
\hline 30 & $11.1, \mathrm{CH}_{3}$ & $0.86, \mathrm{~d}(5.9)$ & 10 & $9,10,11$ & 9,11 \\
\hline
\end{tabular}


Figure 1. Selected HMBC correlations relevant for the structure elucidation of $\mathbf{1}$.

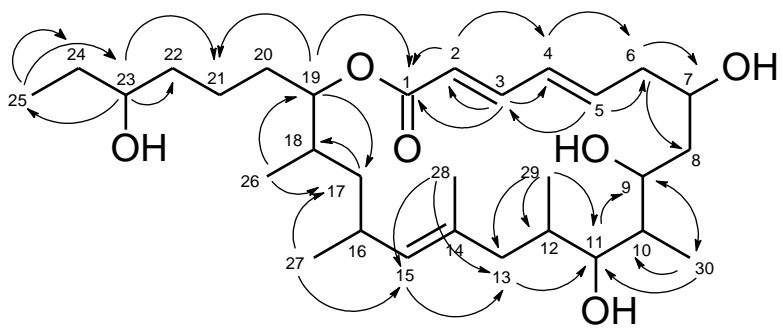

Table 2. NMR spectroscopic data of the levantilides in acetone- $d_{6}(500 \mathrm{MHz})$.

\begin{tabular}{|c|c|c|c|c|}
\hline & \multicolumn{2}{|c|}{ levantilide A (1) } & \multicolumn{2}{|c|}{ levantilide B (2) } \\
\hline & $\delta_{\mathrm{C}}$ & $\delta_{\mathrm{H}}$ & $\delta_{\mathrm{C}}$ & $\delta_{\mathrm{H}}$ \\
\hline 1 & 166.9 & & 166.9 & \\
\hline 2 & 122.0 & 5.83 & 121.9 & 5.83 \\
\hline 3 & 144.3 & 7.14 & 144.4 & 7.15 \\
\hline 4 & 131.9 & 6.36 & 131.9 & 6.36 \\
\hline 5 & 140.1 & 6.09 & 140.2 & 6.11 \\
\hline $6 a$ & 40.6 & 2.69 & 40.6 & 2.66 \\
\hline $6 b$ & & 2.47 & & 2.46 \\
\hline 7 & 69.3 & 4.11 & 69.4 & 4.10 \\
\hline $8 \mathrm{a}$ & 33.8 & 1.73 & 33.9 & 1.72 \\
\hline $8 b$ & & 1.34 & & 1.34 \\
\hline 9 & 69.3 & 4.18 & 69.4 & 4.17 \\
\hline 10 & 42.2 & 1.86 & 42.3 & 1.86 \\
\hline 11 & 77.4 & 3.17 & 77.4 & 3.18 \\
\hline 12 & 33.2 & 1.41 & 33.3 & 1.41 \\
\hline $13 \mathrm{a}$ & 41.4 & 2.00 & 41.4 & 1.99 \\
\hline $13 b$ & & 1.69 & & 1.69 \\
\hline 14 & 134.1 & & 134.1 & \\
\hline 15 & 134.1 & 4.86 & 134.1 & 4.87 \\
\hline 16 & 30.7 & 2.70 & 30.7 & 2.69 \\
\hline $17 \mathrm{a}$ & 41.9 & 1.47 & 41.9 & 1.43 \\
\hline $17 b$ & & 1.12 & & 1.11 \\
\hline 18 & 34.7 & 1.87 & 34.7 & 1.87 \\
\hline 19 & 78.8 & 4.83 & 78.6 & 4.81 \\
\hline $20 \mathrm{a}$ & 28.9 & 1.61 & 28.3 & 1.57 \\
\hline $20 \mathrm{~b}$ & & 1.53 & & 1.50 \\
\hline $21 \mathrm{a}$ & 23.3 & 1.42 & 21.3 & 1.62 \\
\hline $21 b$ & & & & 1.47 \\
\hline 22 & 37.6 & 1.42 & 42.1 & 2.45 \\
\hline 23 & 72.7 & 3.42 & 210.5 & \\
\hline $24 \mathrm{a}$ & 31.1 & 1.43 & 36.0 & 2.42 \\
\hline $24 b$ & & 1.37 & & \\
\hline 25 & 10.4 & 0.90 & 8.0 & 0.96 \\
\hline 26 & 18.6 & 0.91 & 18.4 & 0.91 \\
\hline 27 & 22.0 & 0.86 & 21.8 & 0.87 \\
\hline
\end{tabular}


Table 2. Cont.

\begin{tabular}{lllll}
\hline 28 & 17.6 & 1.62 & 17.6 & 1.63 \\
29 & 18.5 & 0.70 & 18.4 & 0.71 \\
30 & 10.8 & 0.98 & 11.0 & 0.98 \\
\hline
\end{tabular}

The levantilides are macrolides with a 20-membered lactone ring. From a biosynthetic point of view macrolides are typical type I PKS products with very well studied biosynthetic pathways. From the structures of the levantilides, a very simple assembly of a propionate starter unit, five further propionate building blocks and altogether six acetate building blocks can be deduced.

Cytotoxicity tests of $\mathbf{1}$ revealed antiproliferative activities against gastric tumor cells GXF 251L $\left(\mathrm{IC}_{50}=40.9 \mu \mathrm{M}\right)$, lung tumor cells LXFL 529L $\left(\mathrm{IC}_{50}=39.4 \mu \mathrm{M}\right)$, mammary tumor cells MAXF $401 \mathrm{NL}\left(\mathrm{IC}_{50}=28.3 \mu \mathrm{M}\right)$, melanoma tumor cells $\mathrm{MEXF} 462 \mathrm{NL}\left(\mathrm{IC}_{50}=48.6 \mu \mathrm{M}\right)$, pancreas tumor cells PAXF 1657L $\left(\mathrm{IC}_{50}=20.7 \mu \mathrm{M}\right)$ and renal tumor cells $\mathrm{RXF} 486 \mathrm{~L}\left(\mathrm{IC}_{50}=52.4 \mu \mathrm{M}\right)$. Antimicrobial activity against the bacteria and fungi in the test panel were not observed for compounds $\mathbf{1}$ and $\mathbf{2}$.

Members of the Actinomycetes are well known to produce macrolide antibiotics [10]. Micromonospolides, mycinamicins, megalomicin, rosamicin and juvenimicins are e.g., macrolide antibiotics produced by members of the genus Micromonospora, but they all differ in the size of the macrolide ring from the levantilides [11-15]. The levantilides are 20-membered macrolides without an attached sugar and are, for example, related to the cytotoxic macrolides amphidinolide $\mathrm{A}$ and $\mathrm{U}[16,17]$ as well as to iriomoteolide $1 \mathrm{a}, \mathrm{b}$ and $\mathrm{c}[18,19]$. These compounds are also 20 -membered marcolides which exhibit cytotoxic activity against several human tumor cell lines [20-22] and are produced by the marine symbiontic dinoflagellate Amphidinium sp. Iriomotolide 1a, 1b and 1c show remarkable cytotoxicity against B lymphocyte cells DG75 ( $\mathrm{IC}_{50}=0.0039 \mu \mathrm{M}, 1.7 \mu \mathrm{M}$ and $0.0038 \mu \mathrm{M}$ ) while amphidinolide $\mathrm{A}$ and $\mathrm{U}$ possess cytotoxic activities against murein lymphoma cells L1210 $\left(\mathrm{IC}_{50}=3.7 \mu \mathrm{M}\right.$ and $\left.10.7 \mu \mathrm{M}\right)$ and against human epideromoid carcinoma cells $\left(\mathrm{IC}_{50}=10.7 \mu \mathrm{M}\right.$ and $35.08 \mu \mathrm{M})$.

According to Skropeta (2008), polyketide metabolites have been reported from all water depths, but interestingly only $8 \%$ of the marine natural products known so far are produced by organisms obtained at depth greater than $1000 \mathrm{~m}$ [23]. As a matter of course, this might be due to the fact that the deep sea is hardly accessible. In the present study, it was shown by cultivation of strain M71-A77 with habitat sea water (38.6\%) that levantilides are also produced under the high salinity conditions occurring in situ in the Mediterranean Sea. Though strains of Micromonospora spp. were frequently isolated from deep sea habitats [24-26], to the best of our knowledge the levantilides are the first natural products described from a Micromonospora sp. strain isolated from the deep sea.

\section{Experimental Section}

\subsection{Isolation and identification of strain M71-A77}

Strain M71-A77 has been isolated from a sediment core (1.5-5 cm sediment horizon) from $4400 \mathrm{~m}$ depth during a research cruise with RV Meteor M71/2 in the Eastern Mediterranean Sea, the so-called Levantine Sea $\left[34^{\circ} 25.48 \mathrm{~N}, 26^{\circ} 05.39 \mathrm{E}\right]$. One gram of the sediment sample was transferred to a sterile petri dish and dried for 2 months at $20^{\circ} \mathrm{C}$ prior to incubation for $1 \mathrm{~h}$ at $120^{\circ} \mathrm{C}$ dry heat. 
Sediment was then re-suspended in demineralized water and inoculated on agar plates of XJ4-medium containing of $1 \mathrm{~L}$ of demineralized water $18 \mathrm{~g}$ agar, $0.1 \mathrm{~g}$ histidine, $1 \mathrm{~g}$ raffinose, $0.5 \mathrm{~g}$ sodium hydrogen phosphate, $1.7 \mathrm{~g}$ potassium chloride, $0.05 \mathrm{~g}$ magnesium sulfate, $0.01 \mathrm{~g}$ iron sulfate, $0.02 \mathrm{~g}$ calcium carbonate, $0.5 \mathrm{mg}$ thiamine hydrogen chloride, $0.5 \mathrm{mg}$ riboflavine, $0.5 \mathrm{mg}$ niacine, $0.5 \mathrm{mg}$ piridoxin, $0.5 \mathrm{mg}$ calcium pantothenate, $0.5 \mathrm{mg}$ inositol, $0.5 \mathrm{mg}$ para aminobenzoic acid and $0.25 \mathrm{mg}$ biotin. After 2 months of incubation at $28{ }^{\circ} \mathrm{C}$, strain M71-A77 was isolated by transferring to fresh XJ4-medium. The strain was classified by $16 \mathrm{~S}$ rRNA gene sequence analysis according to Gärtner et al. [27]. The 16S rRNA gene sequence was deposited in the EMBL Nucleotide Sequence Database and was assigned the accession no. FR714833.

\subsection{Chemical analysis}

General experimental procedures. The optical rotation was measured on a Perkin Elmer model 241 polarimeter. UV-spectra were obtained on a NanoVue (GE Healthcare). NMR spectra were recorded on a Bruker DRX500 spectrometer (500 and $125 \mathrm{MHz}$ for ${ }^{1} \mathrm{H}$ and ${ }^{13} \mathrm{C}$ NMR, respectively), using the signals of the residual solvent protons and the solvent carbons as internal references $\left(\delta_{\mathrm{H}} 2.04\right.$ and $\delta_{\mathrm{C}} 28.9 \mathrm{ppm}$ for acetone- $d_{6} ; \delta_{\mathrm{H}} 2.50$ and $\delta_{\mathrm{C}} 39.51 \mathrm{ppm}$ for DMSO- $d_{6}$ ). High-resolution mass spectra were acquired on a benchtop time-of-flight spectrometer (MicrOTOF, Bruker Daltonics) with positive electrospray ionization. Analytical reversed phase HPLC-UV/MS experiments were performed using a $\mathrm{C}_{18}$ column (Phenomenex Onyx Monolithic $\mathrm{C} 18,100 \times 3.00 \mathrm{~mm}$ ) applying an $\mathrm{H}_{2} \mathrm{O}$ (A)/MeCN (B) gradient with $0.1 \% \mathrm{HCOOH}$ added to both solvents (gradient: 0 min 5\% B, 4 min $60 \%$ B, 6 min 100\% B; flow $2 \mathrm{~mL} / \mathrm{min}$ ) on a VWR Hitachi Elite LaChrom system coupled to an ESI-ion trap detector (Esquire 4000, Bruker Daltonics). Preparative HPLC was carried out using a Phenomenex Gemini C18 110A AXIA, $100 \times 50.00$ mm column.

Isolation of levantilides A and B. $10 \mathrm{~L}$ of liquid starch-peptone medium (1L demineralized water $10 \mathrm{~g}$ starch, $5 \mathrm{~g}$ soja peptone, $15 \mathrm{~g}$ Tropic Marin ${ }^{\circledR}$ sea salt and $1 \mathrm{~g}$ calcium carbonate) were used for cultivation of strain M71-A77. After 8 days of incubation $\left(28^{\circ} \mathrm{C}, 125 \mathrm{rpm}\right)$, the culture supernatant was separated from the cells by centrifugation at 10,000 rpm for $10 \mathrm{~min}$ (Beckman J2-MC). Cell pellets were suspended in methanol and homogenized three times with an Ultra Turax T25 basic (IKA-Werke GmbH \& Co., Staufen, Germany) at $17.500 \mathrm{U} / \mathrm{min}$ for $1 \mathrm{~min}$. After additional centrifugation, the methanol extract was decanted and dried. The culture broth supernatant was extracted with ethylacetate (1:1). The dried extracts were dissolved in methanol and analyzed by HPLC-UV/MS. Levantilides A and B were detected at 4.2 and $4.5 \mathrm{~min}$ with a maximum UV-absorption at $260 \mathrm{~nm}$. For structure analysis, $\mathbf{1}$ and $\mathbf{2}$ were separated by reversed phase HPLC. For that purpose, $\mathrm{HCOOH}(0.1 \%)$ was added to the solvents $\mathrm{H}_{2} \mathrm{O}(\mathrm{A})$ and $\mathrm{MeCN}(\mathrm{B})$ and a gradient from $10 \% \mathrm{~B}$ over $60 \% \mathrm{~B}$ (reached after $17 \mathrm{~min}$ ) to $100 \% \mathrm{~B}$ was applied (flow $15 \mathrm{~mL} / \mathrm{min}$ ). Levantilides A and $\mathrm{B}$ were detected at 16.6 and $17.8 \mathrm{~min}$. Thus, $7 \mathrm{mg}$ of $\mathbf{1}$ and $3 \mathrm{mg}$ of $\mathbf{2}$ were obtained.

Levantilide A (1): colorless, amorphous solid; $[\alpha]^{20}{ }_{\mathrm{D}}-72.4$ (c 0.145, MeOH); UV (MeOH) $\lambda_{\max }$ $(\log \varepsilon) 262$ (4.61); for 1D and 2D NMR data see Table 1 and SI; HRESIMS $m / z 531.3676[\mathrm{M}+\mathrm{Na}]^{+}$ $\left(\mathrm{C}_{30} \mathrm{H}_{52} \mathrm{NaO}_{6}, 531.3656\right)$. 
Levantilide B (2): colorless, amorphous solid; $[\alpha]^{20}{ }_{\mathrm{D}}-97.5(c 0.04, \mathrm{MeOH}) ; \mathrm{UV}(\mathrm{MeOH}) \lambda_{\max } 261$ $(\log \varepsilon)(4.48) ;{ }^{1} \mathrm{H}$ NMR (acetone- $\left.d_{6}, 500 \mathrm{MHz}\right) \delta 7.15(1 \mathrm{H}, \mathrm{dd}, J=15.1,11.0, \mathrm{H}-3), 6.36(1 \mathrm{H}, \mathrm{dd}$, $J=15.1,11.0, \mathrm{H}-4), 6.11(1 \mathrm{H}, \mathrm{ddd}, J=15.1,9.8,4.4, \mathrm{H}-5), 5.83(1 \mathrm{H}, \mathrm{d}, J=15.1, \mathrm{H}-2), 4.87(1 \mathrm{H}, \mathrm{d}$, $J=8.0, \mathrm{H}-15), 4.81$ (1H, dt, $J=10.2,2.5, \mathrm{H}-19), 4.17$ (1H, dt, $J=11.9,3.1, \mathrm{H}-9), 4.10$ (1H, m, H-7), 3.18 (1H, m, H-11) 2.69 (1H, m, H-16), 2.66 (1H, m, H-6a), 2.46 (1H, m, H-6b), 2.45 (2H, m, H $\left.{ }_{2}-22\right)$, $2.42\left(2 \mathrm{H}, \mathrm{q}, J=7.5, \mathrm{H}_{2}-24\right), 1.99$ (1H, m, H-13a), 1.87 (1H, m, H-18), $1.86(1 \mathrm{H}, \mathrm{m}, \mathrm{H}-10), 1.72(1 \mathrm{H}$, ddd, $J=15.0,11.2,3.3, \mathrm{H}-8 \mathrm{a}), 1.69(1 \mathrm{H}, \mathrm{dd}, J=13.1,10.9, \mathrm{H}-13 \mathrm{~b}), 1.63$ (3H, s, $\left.\mathrm{H}_{3}-28\right), 1.62$ (1H, m, H-21a), 1.57 (1H, m, H-20a), 1.50 (1H, m, H-20b), 1.47 (1H, m, H-21b), 1.43 (1H, m, H-17a), 1.41 (1H, m, H-12), 1.34 (1H, ddd, J = 15.0, 5.4, 3.0, H-8b), 1.11 (1H, ddd, $J=14.6,9.0,5.1, \mathrm{H}-17 \mathrm{~b}), 0.98$ $\left(3 \mathrm{H}, \mathrm{d}, J=7.0, \mathrm{H}_{3}-30\right), 0.96\left(3 \mathrm{H}, \mathrm{t}, J=7.5, \mathrm{H}_{3}-25\right), 0.91\left(3 \mathrm{H}, \mathrm{d}, J=7.5, \mathrm{H}_{3}-26\right), 0.87(3 \mathrm{H}, \mathrm{d}, J=7.0$, $\mathrm{H}_{3}$-27), $0.71\left(3 \mathrm{H}, \mathrm{d}, J=7.0, \mathrm{H}_{3}-29\right)$; for ${ }^{13} \mathrm{C}$ NMR data see Table 2; HRESIMS $\mathrm{m} / z$ 529.3509 $[\mathrm{M}+\mathrm{Na}]^{+}\left(\mathrm{C}_{30} \mathrm{H}_{50} \mathrm{NaO}_{6}, 529.3500\right)$.

\subsection{Production of levantilide A (1) and B (2) at in situ salinity}

Strain M71-A77 was tested for the production of secondary metabolites at habitat salinity (38.6\%o). For that purpose, Tropical Marine ${ }^{\circledR}$ salt and aqua dest. were replaced by Mediterranean Sea water obtained from the sampling site. After 8 days of cultivation at $28{ }^{\circ} \mathrm{C}$, the culture broth was extracted with ethylacetate and analyzed by analytical HPLC-UV/MS as described above.

\subsection{Antimicrobial tests}

Antimicrobial activity of compound 1 and $2(100 \mu \mathrm{M})$ was tested against the Gram-positive bacteria Bacillus subtilis (DSM 347), Staphylococcus lentus (DSM 6672), the Gram-negative bacteria Xanthomonas campestris (DSM 2405), Escherichia coli (DSM 498), Erwinia amylovora (DSM 50901), Pseudomonas fluorescens (NCIMB 10586), Pseudomonas syringae (DSM 50252), Ralstonia solanacearum (DSM 9544), the yeast Candida glabrata (DSM 6425) and the fungus Septoria tritici as described by Lang et al. in 2007 [28]. The results were compared to a positive (100 $\mu \mathrm{M}$ chloramphenicol for bacteria and $100 \mu \mathrm{M}$ cycloheximide for C. glabrata and S. tritici) and a negative (no compound) control on the same plate.

\subsection{Cytotoxic tests}

The in vitro antiproliferative activities of compound $\mathbf{1}$ against the gastric cancer cell line GXF 251L, lung cancer cell line LXFL 529L, melanoma cancer cell line MEXF 462NL, mammary cancer cell line MAXF 401NL, renal cancer cell line RXF 486L and pancreatic cancer cell line PAXF 1657L were determined by Oncotest $\mathrm{GmbH}$ (Freiburg, Germany) using a modified propidium iodide monolayer assay [29]. Compound 2 was not tested by Oncotest $\mathrm{GmbH}$, for there was not enough left of the compound.

\section{Acknowledgement}

We thank G. Kohlmeyer-Yilmaz, M. Höftmann and F. Sönnichsen for running and processing NMR experiments at the Otto-Diels Institute of Organic Chemistry (Christian-Albrechts University of 
Kiel, Germany). We also thank U. Drieling (Otto-Diels Institute of Organic Chemistry (ChristianAlbrechts University of Kiel, Germany)) for giving us the opportunity and assisting us with the measurement of the optical rotation. The authors gratefully thank A. Erhard, S. Malien, K. Schumann, R. Koppe and R. Wicher ${ }^{\dagger}$ for technical assistance. Thanks to J.B. Speakman from BASF for providing the strain S. tritici. This study was performed at the Kieler Wirkstoff-Zentrum (KiWiZ) at the IFM-GEOMAR (Leibniz Institute of Marine Sciences). The KiWiZ is supported by the Ministry of Sciences, Economic Affairs and Transport of the State of Schleswig-Holstein (Germany) in the frame of the "Future Program for Economy" which is co-financed by the European Union (EFRE).

\section{Supplementary Information}

${ }^{1} \mathrm{H}$ NMR spectra, ${ }^{13} \mathrm{C}$ NMR spectra, COSY spectra and HMBC spectra of compounds $\mathbf{1}$ and $\mathbf{2}$ as well as the NMR spectroscopic data of compound $\mathbf{2}$ are available as supplementary information.

\section{References}

1. Lam, K.S. Discovery of novel metabolites from marine actinomycetes. Curr. Opin. Microbiol. 2006, 9, 245-251.

2. Berdy, J. Bioactive microbial metabolites. J. Antibiot. 2005, 58, 1-26.

3. Jensen, P.R.; Mincer, T.J.; Williams, P.G.; Fenical, W. Marine actinomycete diversity and natural product discovery. Antonie van Leeuwenhoek 2005, 87, 43-48.

4. Fiedler, H.P.; Bruntner, C.; Bull, A.T.; Ward, A.C.; Goodfellow, M.; Potterat, O.; Puder, C.; Mihm, G. Marine actinomycetes as a source of novel secondary metabolites. Antonie van Leeuwenhoek 2005, 87, 37-42.

5. Magarvey, N.A.; Keller, J.M.; Bernan, V.; Dworkin, M.; Sherman, D.H. Isolation and characterization of novel marine-derived actinomycete taxa rich in bioactive metabolites. Appl. Environ. Microbiol. 2004, 70, 7520-7529.

6. Bernan, V.S.; Greenstein, M.; Carter, G.T. Mining marine microorganisms as a source of new antimicrobials and antifungals. Curr. Med. Chem.-Anti-Infect. Agents 2004, 3, 181-195.

7. Hohmann, C.; Schneider, K.; Bruntner, C.; Irran, E.; Nicholson, G.; Bull, A.T.; Jones, A.L.; Brown, R.; Stach, J.E.M.; Goodfellow, M.; et al. Caboxamycin, a new antibiotic of the benzoxazole family produced by the deep-sea strain Streptomyces sp. NTK 937*. J. Antibiot. 2009, 62, 99-104.

8. Hohmann, C.; Schneider, K.; Bruntner, C.; Brown, R.; Jones, A.L.; Goodfellow, M.; Kramer, M.; Imhoff, J.F.; Nicholson, G.; Fiedler, H.P.; et al. Albidopyrone, a new [alpha]-pyrone-containing metabolite from marine-derived Streptomyces sp. NTK 227*. J. Antibiot. 2009, 62, 75-79.

9. Thingstad, T.F.; Krom, M.D.; Mantoura, R.F.C.; Flaten, G.A.F.; Groom, S.; Herut, B.; Kress, N.; Law, C.S.; Pasternak, A.; Pitta, P. Nature of phosphorus limitation in the ultraoligotrophic Eastern Mediterranean. Science 2005, 309, 1068-1071.

10. Katz, L.; Ashley, G.W. Translation and protein synthesis: macrolides. Chem. Rev. 2005, 105, 499-528. 
11. Ohta, E.; Ohta, S.; Kubota, N.K.; Suzuki, M.; Ogawa, T.; Yamasaki, A.; Ikegami, S. Micromonospolide A, a new macrolide from Micromonospora sp. Tetrahedron Lett. 2001, 42, 4179-4181.

12. Weinstein, M.J.; Wagman, G.H.; Marquez, J.A.; Testa, R.T.; Oden, E.; Waitz, J.A. Megalomicin, a new macrolide antibiotic complex produced by Micromonospora. J. Antibiot. 1969, 22, 253-258.

13. Hatano, K.; Higashide, E.; Shibata, M. Studies on juvenimicin, a new antibiotic I. J. Antibiot. 1976, 29, 1163-1170.

14. Satoi, S.; Muto, N.; Hayashi, M.; Fujii, T.; Otani, M. Mycinamicins, new macrolide antibiotics. I. J. Antibiot. 1980, 33, 364-376.

15. Waitz, J.A.; Drube, C.G.; Moss, E.L.; Weinstein, M.J. Biological studies with rosamicin, a new micomonospora-produced macrolide antibiotic. J. Antibiot. 1972, 25, 647-652.

16. Kobayashi, J.; Ishibashi, M.; Nakamura, H.; Ohizumi Terufumi, Y. Amphidinolide-A, a novel antineoplastic macrolide from the marine dinoflagellate sp. Tetrahedron Lett. 1986, 27, 5755-5758.

17. Tsuda, M.; Endo, T.; Kobayashi, J. Amphidinolide U, novel 20-membered macrolide from marine dinoflagellate amphidinium sp. Tetrahedron 1999, 55, 14565-14570.

18. Tsuda, M.; Oguchi, K.; Iwamoto, R.; Okamoto, Y.; Fukushi, E.; Kawabata, J.; Ozawa, T.; Masuda, A.; Kitaya, Y.; Omasa, K. Iriomoteolide-1a, a potent cytotoxic 20-membered macrolide from a benthic dinoflagellate Amphidinium species. J. Org. Chem. 2007, 72, 4469-4474.

19. Tsuda, M.; Oguchi, K.; Iwamoto, R.; Okamoto, Y.; Fukushi, E.; Kawabata, J.; Ozawa, T.; Masuda, A. Iriomoteolides-1b and -1c, 20-membered macrolides from a marine dinoflagellate Amphidinium species. J. Nat. Prod. 2007, 70, 1661-1663.

20. Kobayashi, J.; Tsuda, M. Amphidinolides, bioactive macrolides from symbiotic marine dinoflagellates. Nat. Prod. Rep. 2004, 21, 77-93.

21. Kobayashi, J.; Ishibashi, M. Bioactive metabolites of symbiotic marine microorganisms. Chem. Rev. 1993, 93, 1753-1769.

22. Kobayashi, J.; Kubota, T. Bioactive macrolides and polyketides from marine dinoflagellates of the genus Amphidinium. J. Nat. Prod. 2007, 70, 451-460.

23. Skropeta, D. Deep-sea natural products. Nat. Prod. Rep. 2008, 25, 1131-1166.

24. Pathom-aree, W.; Stach, J.; Ward, A.; Horikoshi, K.; Bull, A.; Goodfellow, M. Diversity of actinomycetes isolated from Challenger Deep sediment $(10.898 \mathrm{~m})$ from the Mariana Trench. Extremophiles 2006, 10, 181-189.

25. Prieto-Davo, A.; Fenical, W.; Jensen, P.R. Comparative actinomycete diversity in marine sediments. Aquat. Microb. Ecol. 2008, 52, 1-11.

26. Colquhoun, J.A.; Heald, S.C.; Li, L.; Tamaoka, J.; Kato, C.; Horikoshi, K.; Bull, A.T. Taxonomy and biotransformation activities of some deep-sea actinomycetes. Extremophiles 1998, 2, 269-277.

27. Gärtner, A.; Wiese, J.; Imhoff, J.F. Amphritea atlantica gen. nov., sp. nov., a gammaproteobacterium from the Logatchev hydrothermal vent field. Int. J. Syst. Evol. Microbiol. 2008, 58, 34-39. 
28. Lang, G.; Wiese, J.; Schmaljohann, R.; Imhoff, J.F. New pentaenes from the sponge-derived marine fungus Penicillium rugulosum: structure determination and biosynthetic studies. Tetrahedron 2007, 63, 11844-11849.

29. Dengler, W.A.; Schulte, J.; Berger, D.P.; Mertelsmann, R.; Fiebig, H.H. Development of a propidium iodide fluorescence assay for proliferation and cytotoxicity assays. Anti-Cancer Drugs 1995, 6 .

(C) 2011 by the authors; licensee MDPI, Basel, Switzerland. This article is an open access article distributed under the terms and conditions of the Creative Commons Attribution license (http://creativecommons.org/licenses/by/3.0/). 